\title{
Green, Green Grass of Home
}

Our old grey Subaru crept slowly up the dusty gravel road. It was a muggy evening, but you couldn't turn the air con on or open any windows unless you wanted a car full of dust. I got to sit in the front for this last stretch to Nanny's, so I oversaw switching out Dad's Prince Tui Teka CDs. Dad went extra slow so as not to scratch the discs, but that was hard on a gravelly road full of potholes.

I watch in the headlights as swarms of bugs get swallowed up in the hood of the car, while the final chorus of E Ipo is blasting on the stereo. Well, at least they got a farewell from the prince.

We would always listen to the same handful of CDs every time we made the long drive back home to the valley. But Prince Tui Teka was my favourite. All the jokes the prince would crack in the interludes would have everyone in the car laughing, and the epic ballads would have even quiet old Mum singing at the top of her lungs! Yeah, it was mean alright, we never did stuff like this back in the city.

We were behind schedule since we left a little late, and every turn along the windy road looked the 
same in the dark. But now and then, a break in the heavy bush alongside the road would reveal the Auraki river, lit up in Marama's warm glow. Each night I noticed her getting bigger as she followed me all the way from the city. Auraki sparkles under her even though she is still not at her brightest! Man, I used to talk to her all the time when I was little. About my day or what I had gotten up to at kura that week. It seems silly now, but I liked to stare up at her and tell her all my secrets. It was nice to have someone to talk to because I was a bit like Mum. Quiet and shy, so I didn't have many friends. Of course, Marama would never reply but I liked to think she was always listening. I haven't done that in a long time feels like.

Suddenly we've arrived at Nan's bumpy paddock driveway, welcomed back by a chorus of moos and glowing pairs of eyes floating in the dark. Nan's whare is warm and inviting and there's miti tahu sitting in the oven she says. We were all tired from the trip, but I always felt good at Nan's, warm and safe. "How are you my moko. Haere mai"

A lasting soft hug, and I'm surrounded by the smell of her favourite perfume. "Help me set the table moko and we can all have a cuppa tea." After a catch up and a kai, Dad and Uncle retire to the lounge to watch the game. The blue glow of the screen lights up the brothers' faces, keenly watching a tight scrum. If I squint enough, the light just catches the faces behind Dad and Uncle, housed in the mismatched picture frames hanging up on the walls of Nan's whare. Cousins, aunties, uncles and kaumatua, most of whom I didn't really know. Still, I liked to look at each picture, it was comforting to 
know I had so much whānau. "We're heading over to the marae in the morning." Dad absentmindedly mentions. The marae? I have vague memories of tangi and gatherings there. Strangers asking why I was hiding behind Dad's leg, mostly women with silver streaks in their dark black hair looking down at me with wrinkled eyes and warm smiles. They would kiss me on the cheek and envelope me in a heartfelt embrace. Hey! Who are you lady!? But I would never say that of course. But going over to the marae made me nervous and uneasy. I didn't really know anyone, and would they even remember me?

"Come on Bub, time to go. We gotta get there early to help out." A cold brisk morning with bright blue skies greeted us the next day. It was going to be a beautiful day in the valley. Dad hurried us all out of Nan's and out into the paddock. The marae was just a few over. We had to walk carefully across Koro Jack Tuhoi's paddock, sometimes he left his hunting dogs off the leash. Big ugly mutts they were, with jaws strong enough to take down a poaka nunui! We walked quietly alright. We jumped the last fence over into the Marae grounds and made our way to the wharekai. It was a bit muddy near the Waharoa from the morning drizzle, so I tiptoed carefully around the sludge in my sneakers.

"Don't you have gumboots?" a young boy called out from the steps of the wharenui. Well, no I didn't, but that's because I didn't really need them back in the city. The boy giggled as I almost slipped on the last of the muddy patch. Dad hurried me up while I shrunk from embarrassment.

"Come say hello to your uncles bub!" 
"Hau is that little Aniwa! Look at you, all grown up aye girl!" A name vaguely sprung to mind for the kindly face covered in whiskers sitting near the doorway of the wharekai. The other fulla in the blue overalls however, I had no clue who he was.

"Haven't seen this one in years Tiki, don't you wanna bring the kids back here?" Blue overalls jokingly said to Dad. Once we stepped inside, everything was all go, with cleaning underway and kai being prepared for the celebration tomorrow. The kitchen out the back was full of ringawera and you could see the hangi pit being dug just out the backdoor. "That's me Bub, your uncles and I will be out back for the day, you go and play with the other kids." Dad leaves me on my own to go help.

There were some kids just at the edge of the marae grounds, near the river getting ready for a swim. The uneasy feeling has come creeping back. Without Dad to show me around I felt out of place, like an outsider. I wasn't the greatest at making friends because I was shy, and all these kids knew each other so well.

The boy from the wharenui steps notices me standing from afar. "Hey girl! Found your gumboots yet?!" All the other kids laugh, and it makes me upset. I quickly leave, but don't see the muddy patch in front of me and I slip and fall face first into the brown sludge. The kids must see cause the laughter just gets louder. I just know my whole face is red underneath the smelly mud. Bloody hell! My face starts to warm up and I don't wanna cry because the kids will just make fun of me even more! I can't remember where the toilets are, so I run to ask Dad, 
making my way through the Wharekai to find him. A voice suddenly roars at me, "HEY! GET OUTTA HERE GIRL!! Pai kare dredging all that paru in here! We've just cleaned the floors!" It was one of the ringawera.

"Oh no, I didn't mean to!" I was just trying to find Dad.

"What's your name girl!? I don't even know who all these bloody kids running around are!" I shrunk under her glare. I try to leave hastily, but I stumble backwards and knock over a stack of chairs set aside for the manuhiri. They come tumbling down spectacularly, knocking over even more stacked chairs. "PUTA KI WAHO INĀIANEI!!" the ringawera yells. The ruckus causes all the kids to come over, as well as the unfamiliar uncles, who all see me being told off. I knew for sure my face was red now after that growling, and all my clothes were dirty and covered in mud, only adding to my embarrassment. The kids were giggling again, and the uncles were giving me funny looks and it's just all too much! I run as fast as I can back to Nan's whare, with tears welling up in my eyes.

Nan and Mum have made us all a nice dinner for the night, but I'm still too shamed to even eat. I'm all clean now but I still feel like shit after what happened. I excuse myself from the table and go out into the paddock. Besides the few clouds blocking the moonlight, it's a clear starry night and the air is still warm. I make my way down to the river just down the hill behind Nan's whare. You gotta watch out for the blackberry in the field just before you reach the stony bank of the river, unless you want 
your feet all cut up. Not that I would care right now since I feel so stink. I sit on some warm stones in front of the river with its rushing but steady currents and ohhh bloody hell I'm crying again! Why did she have to yell at me like that? And why did the kids have to be so mean? I already felt like I didn't fit in at the marae, unneeded and a nuisance. Why do I feel this way? I thought this was my home! Right now, the only place I want to be is back in the city, at least I didn't feel this way there. My cheeks are wet with tears when the air stills suddenly.

"He aha te mate e hine?" a deep soothing voice echoes across the river.

“AH! Who's there!?” I quickly look around to find where the voice is coming from. All at once the Auraki river is lit up in the moonlight as the clouds clear.

“Titiro ki runga e hine, ko au tēnei, ko Marama." I look upwards to see Marama has appeared in full, shining brightly in the night sky. No way! It couldn't be!

“Marama?! Why can I hear you?!?” I stammer out.

The voice fills the air around me, as if everywhere at once. "Nā te mea kei te kāinga koe, he uaua te rongo i au ki te roto i te tāone". Marama speaks to me only in Māori, and I can understand but I have lost so much of my reo that I can only reply in English.

"You mean you were always listening Marama? The whole time?" 
"I ngā wā katoa e hine, tēnā he aha te mate?"

"Oh Marama, I feel so sad and alone. I don't think anyone at the marae likes me, I feel like an outsider, like I don't belong!"

"Kāore tērā i te pono e tai, ki konei takoto ai ōu tūpuna, tōu whānau whānui, otirā, ko tēnei tō tūrangawaewae"

"Then how come it doesn't feel like it?"

"Kāore rātou i te mōhio kee ki a koe e hine, tēnā whakapuaki atu ki a rātou ko wai koe, kaua e whakamā, kaua e mataku." Marama is right, they just don't know me, and I need to give it another go.

"Ok Marama I will try"

"Ka pai e tai, me maumahara koe, e āta mātakitaki ana ahau i a koe i ngā wā katoa pērā ki ngā wā e whiti mai ana te rā i te rangi"

"Tēnā koe Marama, thank you e hoa"

"Hei konā e hine..." Marama's soothing voice drifts off, getting lost in the rushing current of the river. It was dark again as the clouds overtake Marama, but I feel so much better now, comforted by her wise words. Tomorrow I would go to the marae and show them just who I was.

I'm up early and ready to go as soon as the sun is up. "Gee Bub, I didn't think you'd be so keen to go back to the marae after yesterday." Dad gave me a worried look, but I could see the slight smile he had 
as well. I knew he'd he be happy that I was trying again.

"I gotta give it another go Dad, like Prince Tui Teka said, 'There's nothing like the green, green grass of home!' or something like that."

Dad had a good laugh at that. "Ka pai Bub. Well come on then, if we go early Auntie Hari might give us the tester fried bread!"

We make our way over and this time I have some gumboots Nan had set aside for me. I walk proudly through the waharoa this time. "Hey muddy girl! I see you found some gumboots finally!" It's the boy from the other day, giggling happily to himself.

“My name isn’t 'Muddy girl.' Its Aniwa you egg!”

"Ea calm down I was just joking! My name is Eddy, short for Eruera." Eddy smiles sweetly, "Sorry about yesterday oi, we didn't mean to make you cry. Man, we always get told off by Auntie Hira, she can be scary like that but she's really all good." Eddy giggles cheekily, "Just don't play up in her wharekai, she's the boss in there."

Eddy starts for the wharekai before turning around and waving to me. "Come Aniwa, let's see if they need any help in the kitchen. That'll get you back on Auntie Hira's good side."

The ringawera from yesterday, Auntie Hira, looks me up and down once we are in the kitchen. "I see the little paru one is back. Here to make another mess girl." 
"Nah Auntie, this is Aniwa and she wants to help out with the big celebration! Aye Aniwa?" Eddy looks over at me.

"Yup! I do Auntie Hira! Anything at all!" I flash my most charming smile and make sure not to look away.

"Aniwa? Well, you must be Tiki's little girl." She gives me a stern stare, then her face softens, "Alright then, haere mai you two, I'll get you on the riwai first."

Eddy and I ended up peeling potatoes, setting tables, washing dishes, and even helping with the pudding! I worked hard and made sure to do everything right. Dad even let me put out the embers from the Hangi, usually a job left for the older kids. I cracked some of the jokes from Dad's CDs with Eddy and the other kids, even getting a chuckle from Auntie Hira. I can thank the prince for that. I realised it wasn't so hard at all once I stopped being so shy. As the day I went on I started to recognise the faces in the frames hanging up in Nan's whare. Uncle Mo with his gap-toothed grin and long white beard. Auntie Honey with the wrinkly eyes and hearty laugh. Twin cousins Jah and Johnny, tall and skinny, who were always trying to skip out on the mahi. All these people were my whānau, and my heart was full to finally know them all. After all the preparation and the big celebration, the kids and I sat on the green grass in front of the wharenui. As the sun went down, I could see Marama peeking over the hills of the valley, and I silently thanked her. With a full puku and a smile on my face, man did it feel good to be home. 